\title{
HAK KEKAYAAN INTELEKTUAL SEBAGAI BENDA: PENELUSURAN DASAR PERLINDUNGAN HKI DI INDONESIA
}

\author{
Indirani Wauran-Wicaksono \\ Staf Pengajar Fakultas Hukum Universitas Kristen Satya Wacana \\ Korespondensi: indirani.wauran@staff.uksw.edu
}

\begin{abstract}
Abstrak
Hak Kekayaan Intelektual memberikan kewenangan hukum kepada seseorang untuk mendapat keuntungan dari karya intelektual yang diciptakan. Hal ini berimplikasi pihak lain, yang tanpa persetujuan, tidak diperbolehkan untuk mengambil keuntungan dari sebuah karya intelektual. Pengambilan keuntungan berarti mengambil sesuatu, di mana sesuatu tersebut berada dalam hukum sipil yang dikenal dengan properti. Artikel ini menyelidiki kembali perlindungan dasar hak kekayaan intelektual untuk memberikan justifikasi bahwa hak kekayaan intelektual adalah 'properti' yang memiliki sifat dasar properti dan faktanya obyek properti memiliki hak milik.
\end{abstract}

Kata-kata Kunci: Hak Kekayaan Intelektual; Benda; Hak Milik.

\begin{abstract}
Abstrak
Intellectual Property Rights provides legal authority for a person to reap the rewards over the intellectual work produced. This has a consequence that the other party without consent must not take advantage of an intellectual work. Reap the rewards of means to take something, which in civil law is known as the property. This article retraces the basic protection of intellectual property rights to provide justification that intellectual property rights are 'property' that have the nature of properties and in fact is the object of property that has proprietary rights.
\end{abstract}

Key Words: Intellectual Property Rights; Property; Proprietary Rights. 


\section{PENDAHULUAN}

Secara umum hak kekayaan intelektual (HKI) dapat dipahami sebagai hak yang dimiliki seorang individu atas hasil karya intelektualnya termasuk untuk menikmati konsekuensi secara materiil dan/atau non-materiil atas karya tersebut. Menggunakan kalimat berbeda, diketahui bahwa yang berhak mengambil buah adalah penanam atau yang diberi hak oleh si penanam. Dengan demikian, HKI mencegah pihak lain untuk menikmati keuntungan secara tanpa hak. Hal ini sejalan dengan definisi the Agreement on Trade-Related Aspects of Intellectual Property Rights (perjanjian TRIPs) yang menerangkan bahwa HKI adalah hak yang dimiliki oleh kreator untuk mencegah pihak lain menggunakan invensi, desain, atau kreasi yang lain. Selain itu. HKI juga dikaitkan dengan hak yang secara hukum dikaitkan dengan upaya kreatif, reputasi yang memiliki nilai ekonomis dan goodwill. ${ }^{1}$

Salah satu tujuan pemberian hak dalam HKI adalah untuk mempromosikan inovasi dan penciptaan pengetahuan produktif. Dapat ditambahkan pula bahwa eksklusivitas yang diberikan oleh HKI mengurangi biaya transaksi, mendorong penyebaran pengetahuan dan merangsang investasi dalam ide-ide berharga secara desentralisasi yang konsisten dengan prinsip-prinsip dasar ekonomi pasar. ${ }^{2}$ Pelindungan HKI juga memiliki peran sentral bagi masa depan, Gallini dan Scotchmer menyatakan bahwa kekayaan intelektual adalah dasar dari ekonomi modern informasi dan Gilbert menekankan bahwa kekayaan intelektual merupakan mesin pertumbuhan ekonomi di negara maju. ${ }^{3}$

Tulisan ini tidak hendak membahas mengenai tujuan dan peran HKI, akan tetapi akan melihat pada landasan adanya perlindungan atas karya intelektual manusia. Bagian pertama tulisan ini akan membahas situasi hipotetis seandainya dunia tanpa perlindungan karya intelektual manusia. Oleh karenanya akan diuraikan mengenai ketidaksetujuan melindungi hasil karya intelektual manusia. Namun demikian pada akhir pembahasan dinyatakan bahwa pengabaian terhadap perlindungan hasil karya intelektual merupakan suatu kesalahan. Hal ini mengantarkan pada pembahasan berikutnya mengenai arti penting adanya title hak pada karya intelektual manusia. Pada bagian ini akan diuraikan mengenai dasar pemikiran mengenai hasil karya intelektual yang kemudian diakui sebagai hak. Pembahasan mengenai hak berlanjut pada bagian yang ketiga, yaitu mengenai pemikiran bahwa karya intelektual diakui sebagai kekayaan, sehingga dapat dikuasai oleh hak, dalam hal ini hak kebendaan. Selanjutnya pada bagian keempat akan dibahas mengenai HKI di Indonesia. Kemudian bagian terakhir adalah kesimpulan.

David I. Bainbridge, Intellectual Property (Financial Times Pitman Publishing 1999) 521.

Mattias Ganslandt, 'Intellectual Property Rights and Competition Policy' (IFN Working Paper No. 726, 2008, Research Institute of Industrial Economics, December 2008) 5.

3 Ibid. 


\section{PEMBAHASAN}

\section{Mengapa Melindungi Intelektual Manusia?}

Bayangkan dunia tanpa ada pengakuan atas hak dalam karya intelektual manusia. Seseorang, sebut saja Arry, membuat karya tulis yang didasarkan pada penelitian dan pemikiran, tentu saja itu membutuhkan waktu, tenaga, upaya, pemikiran, biaya, dan lain-lain sebagai 'pengorbanan' dalam menghasilkan karya tulis tersebut. Kemudian setelah jadi, orang tersebut merilisnya dalam sebuah blog yang tentu saja dapat diakses oleh pengguna internet. Lima menit setelah tulisan tersebut dirilis, sudah ada blog lain yang memuat tulisan yang sama, lima belas menit kemudian bertambah lagi blog yang memuat tulisan yang sama persis dengan tulisan Arry, dan demikian seterusnya. Orang-orang ini melakukan 'copy-paste' atau dengan kata lain melakukan plagiasi atas karya tulis yang dihasilkan oleh Arry. Dunia tanpa perlindungan atas kekayaan intelektual akan membenarkan tindakan-tindakan plagiasi semacam ini. Ditambah pula dengan tambahan alasan bahwa tindakan plagiasi ini dilakukan demi menghidupi keluarga; membuat tindakan mengambil hasil karya orang lain hanyalah salah satu upaya untuk bertahan hidup. Contoh di atas terjadi dalam lingkup karya tulis, namun dapat juga terjadi dalam dunia karya yang lain misalnya paten, desain industri, atau merek.

Dalam tingkatan lebih tinggi, rezim HKI dipandang sebagai individualistis untuk memonopoli teknologi untuk melindungi investasi (modal). Perkembangan teknologi pada umumnya membutuhkan modal yang cukup besar, karena itu, yang memperoleh perlindungan atas karya intelektual ialah pemilik modal. ${ }^{4}$ Pemberian title 'hak' dalam HKI tidak dapat dipisahkan dari kepentingan ekonomi, dengan demikian, selalu berhubungan dengan perlindungan HKI adalah komersialisasi HKI. ${ }^{5} \mathrm{Hal}$ ini ditegaskan oleh perjanjian TRIPS, bahwa perlindungan HKI tidak dapat dipisahkan dari masalah perdagangan internasional. Perjanjian TRIPs sendiri dipandang sebagai desakan negara maju untuk melindungi kepentingan mereka di bidang HKI. ${ }^{6}$ Sedangkan untuk negara-negara berkembang, perlindungan HKI tidak menguntungkan, tetapi atas desakan negara-negara maju, negara berkembang tidak memiliki pilihan lain selain untuk menandatangani perjanjian. ${ }^{7}$ Pada mulanya perjanjian TRIPs dimaksudkan untuk menetapkan standar minimum perlindungan kekayaan intelektual, tetapi kemudian berkembang menjadi kesepakatan

Agus Sardjono, Hak Kekayaan Intelektual dan Pengetahuan Tradisional (Alumni 2006) 147.

Ibid. 149.

Doris Estelle Long, 'The Impact of Foreign Investment on Indigenous Culture: An Intellectual Property Perspective' (1998) 21 North Caroline Journal of International Law \& Commercial Regulation 229, 249.

$7 \quad$ H.S. Kartadjoemena, GATT, WTO, and Uruguay Round (UI Press 1997) 252-253. 
untuk menciptakan sistem HKI yang berlaku di seluruh dunia dengan cara yang merugikan negara-negara berkembang. ${ }^{8}$

Meskipun secara historis, hukum Indonesia telah lama mengakui perlindungan HKI . jika dilihat dari aspek tradisi dan latar belakang budaya, masyarakat Indonesia tidak akrab dengan konsep perlindungan hak kekayaan intelektual. ${ }^{9}$ Untuk beberapa masyarakat tradisional, seniman dan kaum intelektual memiliki fungsi tertentu dalam masyarakat. Hal ini juga berlaku untuk berbagai karya yang dihasilkan oleh para seniman, pengrajin atau penulis yang biasanya membiarkan karyanya berada pada level domain publik sehingga bisa diakses, direproduksi dan didistribusikan sendiri sesuai dengan kebutuhan individu. ${ }^{10}$

Sebagai contoh di Bali, orang-orang akrab dengan konsep kagunan atau dharma sebagai hak dan kewajiban dari masing-masing individu, yang menggambarkan posisi artis atau pengetahuan intelektual sebagai sumber inspirasi bagi masyarakat. ${ }^{11}$ Tidak aneh jika pada beberapa seniman tradisional dan pengrajin di Bali, orang bebas untuk mereproduksi dan menyebarkan karya seni atau kerajinan yang dihasilkan untuk kebaikan bersama. Namun sayangnya, konsep dharma atau kagunan kemudian bertentangan dengan gagasan HKI. Satu kasus bahwa ada penangkapan seorang pengrajin di Bali (Deni Aryasa) karena diduga membajak desain kerajinan perak milik perusahaan asing. ${ }^{12}$ Namun demikian akhirnya putusan pengadilan dalam kasus itu membebaskan Aryasa dari segala tuduhan karena karya desain perak Bali dianggap telah diwariskan dari generasi ke generasi di kalangan masyarakat Bali. ${ }^{13}$

Ulasan di atas nampaknya memberi alasan untuk tidak melindungi hasil pemikiran intelektual seseorang, nampaknya lebih baik jika semua diserahkan saja menjadi milik umum. Dengan demikian dalam dunia tanpa pengakuan HKI, tidak ada perlindungan bagi seseorang yang mengembangkan ide dan menuangkannya dalam sebuah karya apapun wujudnya. Dengan kata lain, seluruh jerih payah seseorang dalam menghasilkan suatu karya seolah-olah diabaikan begitu saja.

Pendapat di atas tidak dapat dibenarkan, karena sekalipun ide yang dikembangkan dimaksudkan untuk penggunaan atau kepuasan pribadi, upaya dan 'biaya' yang dikeluarkan dalam menghasilkan suatu karya perlu mendapatkan imbalan. ${ }^{14} \mathrm{Hal}$ ini hanya

8 Johny Ibrahim, Hukum Persaingan Usaha. Filosofi, Teori dan Implikasi Penerapannya di Indonesia (Bayumedia 2007) 151.

$9 \quad$ Totok Dwinur Haryanto, 'Kultur Masyarakat dan Hak Kekayaan Intelektual ' (2009) 8 Jurnal Wacana 25, 34.

10 Ibid.

11 Ibid.

12 Ketut Deni Aryasa vs. Republik Indonesia, Putusan MA No. 823 K/Pid.Sus/2009, Mahkamah Agung, 23 Februari 2011.

13 Ibid.

14 Catherine Colston, Principles of Intellectual Property Law (Cavendish Publishing Limited 1999) 2 . 
mungkin terjadi jika ada perlidungan terhadap resiko adanya imitasi atas karya intelektual yang dihasilkan. ${ }^{15}$ Sampai pada titik ini, saatnya hukum melangkah masuk untuk memberikan perlindungan bagi penghasil karya intelektual dalam berbagai bentuk. Tanpa ada perlindungan atas karya intelektual, semangat untuk menghasilkan karya intelektual akan memudar karena secara alamiah, manusia membutuhkan pengakuan dan apresiasi atas karya yang dihasilkan.

\section{Pengakuan atas Hak dalam Karya Intelektual Manusia}

Manusia menghasilkan suatu karya dari hasil olah pikirnya merupakan tindakan produksi. Atas hasil produksi tersebut, dapat diklaim suatu kepemilikian. Manusia melakukan produksi menggunakan intelektualitasnya adalah suatu yang alamiah. Dengan kata lain, manusia memang diciptakan untuk berpikir menggunakan akal dan budinya, manusia yang berpikir adalah manusia yang menjalani kodratnya sebagai manusia. Hal ini sejalan dengan paham pemikiran kaum Stoa mengenai manusia bahwa hakikat manusia dicirikan oleh akal budi. ${ }^{16}$

Oleh karenanya dapat dikatakan bahwa hak merupakan sesuatu yang tidak dapat dipisahkan dari hakikat manusia itu sendiri. ${ }^{17}$ Dengan demikian hak memiliki kedudukan yang tinggi dan sangat berharga. Hal ini dengan sangat baik dikemukakan oleh Feinberg demikian. ${ }^{18}$

Indispensably valuable possessions. A world without them, no matter how full of benevolence and devotion to duty, would suffer an immense moral impoverishment... Rights...are not mere gift or favour ... for which gratitude is the sole fitting response. A right is something that can be demanded or insisted upon without embarrassment or shame ... A word with claim-right is one in which all persons, as actual or potential claimants, are dignified objects of respects ... No amount of love or compassion, or obedience to higher authority, or noblesse oblige, can substitute for those values.

Dikatakan bahwa dunia tanpa hak akan menderita kemiskinan moral yang besar, meskipun ada banyak kebajikan dan pemenuhan kewajiban. Lebih lanjut Feinberg mengatakan bahwa hak adalah sesuatu yang dapat dituntut dan didesak tanpa menjadi malu dan kehilangan harga diri.

Pendapat di atas serupa dengan pandangan Dworkin yang menempatkan hak sebagai sesuatu yang harus dijunjung tinggi oleh siapapun. ${ }^{19}$ Hak bukan diciptakan oleh hukum, namun eksistensi hak memaksa adanya hukum. ${ }^{20}$ Manusia diciptakan dengan aspek fisik dan aspek eksistensial oleh karenanya hak merupakan satu paket

Ibid.

Sony Keraf, Hukum Kodrat dan Teori Hak Milik (Kanisius 1997) 15.

Peter Mahmud Marzuki, Pengantar Ilmu Hukum (Kencana 2008) 174.

Lord Lloyd dan M.D.A. Freeman, An Introduction to Jursiprudence (English Language Book Society 1985) sebagaimana dikutip oleh Peter Mahmud Marzuki, Ibid. 174.

$19 \quad$ Ibid. 178.

$20 \quad$ Ibid. 180. 
dalam penciptaan manusia. Oleh karenanya, diakui atau tidak oleh hukum hak tetap saja ada sebagai bagian dari manusia itu sendiri. ${ }^{21}$ Sejalan dengan Locke yang mengatakan bahwa manusia memiliki hak atas barang milik berkat tenaga fisiknya dan berkat karya tangan atau kerjanya. ${ }^{22}$ Dengan demikian jelas bahwa menurut Locke karya intelektual merupakan hasil kerja manusia, oleh karenanya manusia penghasil karya intelektual memiliki hak atas karya tersebut.

Sampai pada titik ini dapat diketahui bahwa hak melekat pada keberadaan manusia yang secara alamiah selalu berpikir. Manusia yang berpikir dan menghasilkan karya intelektual merupakan manusia yang menjalani haknya sebagai manusia. Oleh karenanya, pada dasarnya atas karya intelektual manusia, diakui atau tidak diakui sudah melekat hak. Dengan demikian, seharusnya tidak lagi menjadi perdebatan dan kebingungan bahwa atas karya intelektual manusia melakat hak yang timbul secara otomatis karena hakikat kemanusiaan itu sendiri.

\section{Kekayaan Intelektual sebagai Hak Kebendaan}

Karya intelektual yang dihasilkan oleh manusia selanjutnya diakui sebagai kekayaan, hal ini berarti ada konsep kepemilikan dan kebendaan yang terkandung didalamnya. Dikaitkan dengan pendapat Locke di atas, maka ditegaskan bahwa hak atas hasil kerja manusia, termasuk hasil kerja intelektual merupakan hak milik dari penghasil karya intelektual. Menggunakan kalimat berbeda dapat dikatakan bahwa kekayaan merupakan pengakuan atas adanya milik seseorang. Sejalan dengan hal ini, Locke mengatakan bahwa manusia memiliki hak alamiah yang eksklusif atas tubuhnya, demikian pula manusia memiliki hak eksklusif atas apa yang dihasilkan tubuhnya. ${ }^{23}$ Berdasar pada hal ini, dapat dikatakan bahwa apa yang dihasilkan tubuhnya, termasuk apa yang dihasilkan oleh akal pikirannya sebagai sebuah karya intelektual. Oleh karenanya, secara logis dapat dinyatakan bahwa berdasar pada hukum kodrat, karya intelektual yang merupakan hasil dari pekerjaan yang dihasilkan oleh tubuh seorang manusia mengandung eksklusivitas yang dimiliki oleh manusia penghasilnya.

Pengakuan akan kepemilikan secara logis juga mengandung makna adanya pengakuan bahwa kekayaan intelektual merupakan benda. Oleh karenanya atas kekayaan intelektual tersebut melekat hak yang dinamakan hak kebendaan. Apabila dikategorikan menurut sifatnya, hak kekayaan intelektual merupakan benda tidak berwujud, karena kekayaan intelektual merupakan hak. Sesuai dengan ajaran hukum kodrat, pemilik HKI memiliki keleluasaan dan kebebasan untuk bertindak bebas terhadap benda miliknya, dalam hal ini karya intelektual yang dihasilkannya.

Ibid.

Sony Keraf, Op.Cit. 71.

Ibid. 72 . 
Hal penting yang harus diingat adalah kekhususan HKI terkait sifatnya yang merupakan benda tidak berwujud namun terkandung dalam benda yang berwujud. Kepemilikan atas benda berwujud tidak berarti juga memiliki benda tidak berwujud yang terkandung di dalamnya. Dengan demikian, keberadaan HKI dalam suatu benda membatasi keleluasaan tindakan pemilik benda berwujud atas miliknya. Sebagai contoh, seseorang memiliki benda berwujud berupa buku, tidak berarti ia memiliki hak cipta sebagai benda tidak berwujud yang terkandung dalam buku tersebut. Artinya, pemilik buku tidak dapat menggandakan dan menjual buku tersebut tanpa ijin dari pemilik hak cipta atas buku tersebut.

Pengakuan Mengenai Hak Kebendaan yang Melekat Pada Hak Kekayaan Intelektual Dalam Hukum Indonesia

Hukum kodrat memberikan dasar perlindungan bagi hak milik. Dikatakan bahwa setiap orang harus dibiarkan untuk mempertahankan milik pribadinya sendiri dan sebaliknya seseorang tidak boleh mengambil dan mempertahankan untuk dirinya apa yang merupakan milik orang lain. ${ }^{24}$ Pertanyaan yang kemudian muncul adalah apa yang dapat dikuasai oleh hak milik. Jawaban atas pertanyaan ini melekat pada makna yang terkandung dari 'milik' itu sendiri. Kepemilikan berarti memiliki sesuatu, sesuatu ini di dalam ranah hukum diartikan sebagai benda. Dengan demikian dalam setiap kata milik secara implicit mengandung makna kepemilikan atas benda tertentu.

Keadilan menurut Cicero adalah kutamaan moral paling utama, atau 'mahkota kemuliaan semua kutamaan moral, ${ }^{25}$ sehingga ketidakadilan merupakan hal yang fatal bagi kehidupan sosial dan persahabatan antar manusia. ${ }^{26}$ Adapun fungsi utama keadilan adalah menjaga agar seseorang tidak merugikan yang lain, kecuali jika orang lain itu telah melakukan kesalahan. ${ }^{27}$ Oleh karenanya adalah adil jika seseorang mendapatkan haknya dengan tidak melanggar hak orang lain. Dengan demikian dapat dikatakan bahwa melanggar hak orang lain bertentangan dengan keadilan.

Selanjutnya Cicero mengatakan bahwa fungsi kedua dari keadilan yaitu mengarahkan manusia untuk menggunakan hak milik bersama demi kepentingan bersama dan hak milik pribadi demi kepentingan mereka masing-masing. ${ }^{28}$ Mendasarkan pada pendapat ini maka pemilik suatu hak memiliki kebebasan untuk menggunakan miliknya tersebut. Sedangkan segala sesuatu yang dapat dikuasai dengan milik disebut sebagai benda.

24 Ibid.

25 Marcus Tullius Cicero, De Officiis, terjemahan dalam bahasa Inggris oleh Walter Miller (William Heinemann Ltd. 1968) sebagaimana dikutip oleh Sony Keraf, Op.Cit. 17.

26 Ibid.

27 Ibid.

28 Ibid. 53. 
Benda adalah zaak dalam bahasa Belanda. Menurut Pasal 499 Kitab Undang-Undang Hukum Perdata (KUH Perdata), yang diartikan sebagai zaak adalah semua barang dan hak. Selanjutnya diketahui bahwa zaak adalah 'bagian dari harta kekayaan' (vermogensbestanddeel). ${ }^{29}$ Sedangkan yang dimaksud dengan benda dalam arti hukum adalah segala sesuatu yang menjadi objek hak milik. ${ }^{30}$ Hak yang melekat pada suatu benda disebut sebagai hak kebendaan (zakenlijk recht), yaitu suatu hak yang memberikan kekuasaan langsung atas suatu benda, yang dapat dipertahankan terhadap tiap orang. ${ }^{31}$

Sedangkan pengertian hak milik berdasar Pasal 570 KUH Perdata adalah hak untuk menikmati kegunaan suatu kebendaan dengan leluasa, dan untuk berbuat bebas terhadap kebendaan itu dengan kedaulatan sepenuhnya. Dengan dikuasainya benda berdasarkan hak milik maka seseorang memiliki hak untuk untuk menikmati benda tersebut dengan aman tanpa gangguan dari pihak lain. Hal demikian juga mengandung makna bahwa pemilik hak milik yang memiliki kedaulatan penuh atas benda tersebut juga memiliki hak untuk mempertahankan hak yang dimilikinya dari orang lain. Apabila benda yang dikuasai hak milik tersebut diambil oleh orang lain tanpa ijin pemilik hak, maka pemilik hak dapat menuntut pengembalian benda tersebut (Pasal 574 KUH Perdata).

Prinsip dalam pasal 570 BW tersebut merupakan dasar perlindungan HKI. Sebagaimana telah diterangkan dalam bagian sebelumnya bahwa HKI adalah benda yang memiliki hak kebendaan dan dengan sendirinya dapat dikuasai hak milik. Maka secara logis pemilik HKI dapat menggunakan hak kekayaan intelektual miliknya dengan leluasa. Hal ini diperkuat dengan pengaturan dalam Undang-undang terkait HKI (UU No. 29 Tahun 2000 tentang Perlindungan Varietas Tanaman, UU No. 31 Tahun 2000 tentang Desain Industri, UU No. 32 Tahun 2000 tentang Desain Tata Letak Sirkuit Terpadu, UU No. 14 Tahun 2001 tentang Paten, UU No. 15 Tahun 2001 tentang Merek, UU No. 28 Tahun 2014 tentang Hak Cipta) yang menyatakan bahwa pemilik hak memiliki hak eksklusif untuk melaksanakan sendiri atau memberikan persetujuan kepada pihak lain untuk melaksanakan hak tersebut. ${ }^{32}$ Berbuat bebas terhadap benda miliknya (baca: HKI) dapat diartikan bahwa pemilik dapat menggunakan sendiri haknya atau mengijinkan orang lain untuk menggunakan hak tersebut, pada intinya ada kebebasan yang dimiliki oleh pemillik benda (baca: HKI) atas haknya tersebut.

29 Abdulkadir Muhammad, Hukum Perdata Indonesia (Citra Aditya Bakti 1990) 125-126.

Ibid. 126.

Subekti, Pokok-pokok Hukum Perdata (Intermasa 1984) 62.

32 Pasal 1 angka 2 UU No. 29 Tahun 2000; Pasal 4 UU No. 30 Tahun 2000; Pasal 1 angka 5 UU No. 31 Tahun 2000; Pasal 1 angka 6 UU No. 32 Tahun 2000; Pasal 1 angak 1 UU No. 14 Tahun 2001; Pasal 3 UU No. 15 Tahun 2001; Pasal 1 angka 1 UU No. 19 Tahun 2002. 
Pasal 584 KUH Perdata menyebutkan lima cara untuk memperoleh hak milik yaitu dengan cara pendakuan, perlekatan, karena daluarsa, kerena pewarisan, dan adanya penyerahan berdasar atas suatau peristiwa perdata untuk memindahkan hak milik. Ketentuan dasar mengenai pengalihan hak ini diadopsi dalam pengaturan mengenai HKI yang menyebutkan bahwa HKI dapat beralih dengan cara pewarisan, hibah, wasiat, perjanjian tertulis, atau sebab lain yang dibenarkan oleh undang-undang. ${ }^{33}$ Harus pula dipahami bahwa cara peralihan HKI yang disebut sebagai cara lain yang dibenarkan oleh undangundang, bersifat menegaskan bahwa cara peralihan hak milik pada umumnya sebagaimana diatur dalam KUHPerdata berlaku pula dalam lingkup HKI mengingat HKI adalah hak kebendaan.

Pengalihan hak milik selalau mensyaratkan adanya kewajiban untuk melakukan penyerahan. Mengingat HKI dikategorikan sebagai benda bergerak yang tidak berwujud, maka penyerahannya dilakukan dengan cara membuat akta baik akta otentik maupun akta dibawah tangan yang menyatakan adanya perpindahan kepemilikan atas HKI. ${ }^{34}$ Bahkan UU HKI (kecuali UU No. 28 Tahun 2014) mensyaratkan apabila terjadi perpindahan kepemilikan wajib dicatatkan dalam daftar umum di Direktorat Jenderal HKI, selanjutnya juga dikatakan bahwa pengalihan yang tidak dicatatkan tidak berakibat hukum kepada pihak ketiga. ${ }^{35}$ Sampai pada titik ini dapat dikatakan bahwa HKI dalam hukum Indonesia secara tegas diatur sebagai benda yang atasnya melekat hak kebendaan sehingga dapat dikuasai oleh hak milik.

\section{PENUTUP}

Dunia tanpa perlindungan HKI adalah dunia dimana tidak ada penghargaan terhadap sifat alamiah manusia yang memiliki akal dan budi untuk berpikir. Atas karya intelektual manusia tersebut secara otomatis melekat hak. Dalam hukum perdata, hak kekayaan intelektual dikategorikan sebagai benda, dalam hal ini benda tidak berwujud.

Diketahui bahwa atas sebuah benda mengandung hak kebendaan sehingga dapat dikatakan benda dapat dikuasai dengan hak milik. Dengan demikian atas HKI sebagai benda yang dilekati hak kebendaan secara logis dapat dikuasai dengan hak milik. Pengakuan mengenai HKI sebagai hak kebendaan diakui dalam hukum Indonesia. Bahkan UU

33 Pasal 40 ayat (1) UU No. 29 Tahun 2000; Pasal 5 ayat (1) UU No. 30 Tahun 2000; Pasal 31 ayat (1) UU No. 31 Tahun 2000; Pasal 23 ayat (1) UU No. 32 Tahun 2000; Pasal 66 ayat (1) UU No. 14 Tahun 2001; Pasal 40 ayat (1) UU No. 15 Tahun 2001; Pasal 16 ayat (2) UU No. 28 Tahun 2014.

34 Pasal 40 ayat (2) UU No. 29 Tahun 2000; Pasal 5 ayat (2) UU No. 30 Tahun 2000; Pasal 31 ayat (2) UU No. 31 Tahun 2000; Pasal 23 ayat (2) UU No. 32 Tahun 2000; Pasal 66 ayat (2) UU No. 14 Tahun 2001; Pasal 40 ayat (2) UU No. 15 Tahun 2001.

35 Pasal 40 ayat (3) UU No. 29 Tahun 2000; Pasal 5 ayat (3)-(4) UU No. 30 Tahun 2000; Pasal 31 ayat (3)-(4) UU No. 31 Tahun 2000; Pasal 23 ayat (3)-(4) UU No. 32 Tahun 2000; Pasal 66 ayat (3)-(4) UU No. 14 Tahun 2001; Pasal 40 ayat (3)-(5) UU No. 15 Tahun 2001. 
dalam ruang lingkup HKI mengakui secara eksplisit HKI sebagai hak kebendaan.

\section{DAFTAR BACAAN}

\section{Buku}

Bainbridge, David I, Intellectual Property (Financial Times Pitman Publishing 1999).

Colston, Catherine, Principles of Intellectual Property Law (Cavendish Publishing Limited 1999).

Ibrahim, Johny, Hukum Persaingan Usaha. Filosofi, teori, dan implikasi penerapannya di Indonesia (Bayumedia 2007).

Kartadjoemena, H.S., GATT, WTO, and Uruguay Round (UI Press 1997).

Keraf, Sony, Hukum Kodrat dan Teori Hak Milik (Kanisius 1997).

Marzuki, Peter Mahmud, Pengantar Ilmu Hukum (Kencana 2008).

Muhammad, Abdulkadir, Hukum Perdata Indonesia (Citra Aditya Bakti 1990).

Sardjono, Agus, Hak Kekayaan Intelektual dan Pengetahuan Tradisional (Alumni 2006).

Subekti, Pokok-pokok Hukum Perdata (Intermasa 1984).

\section{Jurnal}

Haryanto, Totok Dwinur, 'Kultur Masyarakat dan Hak Kekayaan
Intelektual' (2009) 8 Jurnal Wacana 25.

Long, Doris Estelle, 'The Impact of Foreign Investment on Indigenous Culture: An Intellectual Property Perspective' (1998) 21 North Caroline Journal of International Law \& Commercial Regulation 229.

\section{Makalah}

Ganslandt, Mattias, 'Intellectual Property Rights and Competition Policy' (IFN Working Paper No. 726, Research Institute of Industrial Economics, Desember 2008). 